Krzysztof FLASIŃSKI

Uniwersytet Szczeciński

\title{
Stosowanie technik tabloidyzacyjnych jako element strategii wydawniczej w prasie regionalnej - przypadek Szczecina
}

W $\begin{aligned} & \text { dyskursie publicznym określenie „tabloid” występuje w opozycji } \\ & \text { do sformułowania ,gazeta poważna”. „Brukowiec” z zasady sta- }\end{aligned}$ wiany jest w hierarchii jakości informacji dostarczanej czytelnikowi niżej od ,prasy głównego nurtu”. Relacje między dziennikarzami i redaktorami reprezentującymi media stricte tabloidowe, a pracownikami redakcji, które określają się mianem opiniotwórczych lub ogólnoinformacyjnych są skomplikowane. Peter J. Anderson i Geoff Ward zaznaczają, że na rynku brytyjskim ,»)The Sun« zajmujący się skandalami, seksem i życiem gwiazd przypisuje sobie wpływ na życie polityczne przez nieliczne zamieszczane w gazecie artykuły na tematy polityczne, choć taką rolą szczycą się zwykle te bardziej prestiżowe tytuły prasowe. [...] Tymczasem prestiżowe gazety są coraz częściej oskarżane o przejmowanie od prasy brukowej sposobów przedstawiania informacji, ustalania ich hierarchii oraz dobory treści” ${ }^{\prime}$. Jak pisze Zbigniew Bauer, „sukces »tabloidów « wywołał opór wśród dziennikarzy i wydawców - dziennikarstwo w nich uprawiane zaczęto traktować jako negatywny biegun odniesienia dla prasy »poważnej« i »odpowiedzialnej«"2. Zauważalny sukces „Faktu” na polskim rynku prasowym wywołał reakcję wydawców pozostałych dzienników. Mimo wciąż podkreślanego dystansu do tego typu mediów, dziennikarze „poważnych” tytułów stosują jednak niektóre techniki kojarzone z prasą tabloidową. Ogólnie, proces ten nazwać można ta-

1 P. J. Anderson, G. Ward, Wstęp do rozdziału. Główne zagadnienia dotyczace dziennikarstwa $w$ dojrzałych demokracjach, w: Przyszłość dziennikarstwa $w$ dojrzatych demokracjach, red. P. J. Anderson, G. Ward, Warszawa 2010, s. 21.

2 Z. Bauer, ,Twój głos w Twoim domu”: cztery typy tabloidyzacji, w: Oblicza komunikacji. Język i kultura tabloidów. Wrocław 29-30 czerwca 2009. Materiaty konferencyjne, oblicza.konferencja.org/ufiles/File/ksiazka_przedkonferencyjna.pdf, s. 5 . 
bloidyzacją mediów, którą Małgorzata Lisowska-Magdziarz definiuje jako ,zbliżanie formy, języka, obrazu świata w mediach głównego nurtu do treści, formy, języka obrazu świata prasy tabloidowej. W trosce o utrzymanie poziomu czytelnictwa, tak zwanej oglądalności czy liczby słuchaczy, także media dotychczas uważane za poważne zaczynają się odwoływać do tego, co było dotychczas źródłem popularności tabloidów”3.

Należy zadać pytanie, czy proces ten powodowany jest chęcią przejęcia części czytelników prasy bulwarowej, czy jest to raczej ogólny trend w rozwoju dziennikarstwa i redagowania, którego przyczyną są zmieniające się upodobania czytelników. Ryszard Filas wykazuje, że nie należy w prosty sposób wiązać spadku sprzedaży dzienników regionalnych z pojawieniem się na polskim rynku najpopularniejszego tabloidu ${ }^{4}$. Potwierdza jednak, że „Fakt” mógł z powodzeniem konkurować z prasą regionalną dodatkiem telewizyjnym, co w przypadku znaczącej części odbiorców może skutkować rezygnacją z magazynowego wydania dotychczas czytanej gazety regionalnej ${ }^{5}$. Zbigniew Bajka podkreśla natomiast, że już ,po roku 1995 gazety ogólnokrajowe zaczęły uzyskiwać przewagę nad regionalnymi, którą [...] umocniło pojawienie się dwóch ogólnopolskich dzienników: »Faktu« i »Dziennika«"6. Warto dodać, że w tle tych zmian można zauważyć również ewolucję samych tytułów tabloidowych ${ }^{7}$. Niezwykle ważną rolę w tej ewolucji odgrywa również czynnik ekonomiczny. Tadeusz Kowalski zaznacza, że „gazety wtórne” - rozpatrywane w opozycji do ,gazet dominujących” charakteryzujących się silniejszą pozycją na rynku - „starają się dostosować do zmienionej sytuacji na rynku [...] zmieniają formułę, np. na tabloidy" ${ }^{\prime \prime}$.

3 M. Lisowska-Magdziarz, Media powszechne. Środki komunikowania masowego i szerokie paradygmaty medialne $w$ życiu codziennym Polaków u progu XXI wieku, Kraków 2008, s. 199.

4 Badacze mediów zwracają uwagę również na inne zagrożenia dla prasy drukowanej, m.in.: rozwój nowych mediów (szerzej: B. Poulet, Śmierć gazet i przyszłość informacji, Wołowiec 2011) i popularność dziennikarstwa nieprofesjonalnego (więcej: A. Keen, Kult amatora. Jak internet niszczy kulture, Warszawa 2007).

5 R. Filas, Rynek prasy codziennej w Polsce przed „Faktem” i z „Faktem”, „Zeszyty Prasoznawcze” 2005, nr 3-4, s. 26-27.

6 Z. Bajka, Rynek mediów w Polsce, w: Dziennikarstwo i świat mediów. Nowa edycja, red. Z. Bauer, E. Chudziński, Kraków 2008, s. 194.

7 O. Białek-Szwed, ,Super Express” - pierwszy polski tabloid (studium przypadku), ,iNFOTEZY” 2012, nr 1, s. 11-18.

8 T. Kowalski, B. Jung, Media na rynku. Wprowadzenie do ekonomiki mediów, Warszawa 2006, s. 125. 


\section{Opis badań}

Badaniu poddano szczecińską mutację „Głosu Dziennika Pomorza”. Pierwszy numer „Głosu Szczecińskiego” ukazał się 22 sierpnia 1947 r. Do 1990 r. był to oficjalny organ Polskiej Zjednoczonej Partii Robotniczej. Po wejściu w życie ustawy o likwidacji RSW Prasa-Książka-Ruch Komisja Likwidacyjna podpisała ze Spółdzielnią Pracy Głos Szczeciński umowę o przekazaniu tytułu’ ${ }^{9}$ Spółdzielnia była wydawcą „Głosu Szczecińskiego" do 2000 r. Jej członkowie podjęli wtedy decyzję o sprzedaży udziałów, a więc głównie prawa do tytułu i majątku ${ }^{10}$, spółce Orkla Press Polska należącej do obecnej w Polsce od 1990 r. ${ }^{11}$ norweskiej Orkla Media. W 2002 r. pojawił się projekt fuzji mającej doprowadzić do stworzenia struktury zarządzającej redakcjami gazet ukazujących się w różnych miastach. Najbardziej widocznym efektem było ujednoliceniu layoutu oraz przedruki tekstów pochodzących z innych gazet wydawcy. W 2005 r. „Głos” przejęła Media Pomorskie Sp. z o.o. Był to kolejny krok w kierunku połączenia tytułów ze Szczecina, Koszalina i Słupska w jeden. W 2006 roku Orklę zakupił brytyjski fundusz inwestycyjny Mecom Group plc ${ }^{12}$. W 2007 r. nowy właściciel zmienił nazwę spółki na Media Regionalne Sp. z o.o. Proces fuzji był kontynuowany. Ostatni numer „Głosu Szczecińskiego” ukazał się 11 stycznia 2007 r. Od 12 stycznia 2007 r. wydawany jest „Głos Dziennik Pomorza” z trzema mutacjami: szczecińską (dawniej „Głos Szczeciński”), koszalińską (dawniej „Głos Koszaliński”) i słupską (dawniej „Głos Pomorza”). „Głos Dziennik Pomorza" ma jednego redaktora naczelnego oraz jest raportowany w wynikach Związku Kontroli Dystrybucji Prasy oraz Polskich Badań Czytelnictwa jako jeden tytuł. Winiety wszystkich trzech

9 E. Ciborowska, Transformacja prasy byłej PZPR, „Zeszyty Prasoznawcze” 1992, nr 1-2, s. 92.

10 R. Cieślak, Przeobrażenia prasy regionalnej $w$ Zachodniopomorskiem na przykładzie „, Głosu Szczecińskiego”, w: Środki masowego komunikowania a społeczeństwo, red. M. Gierula, Katowice 2006, s. 134.

11 B. Klimkiewicz, Krajobraz medialny w Polsce: struktura własności i pluralizm mediów, w: Własność medialna $i$ jej wplyw na pluralizm oraz niezależność mediów, red. B. Klimkiewicz, Kraków 2005, s. 75.

12 Spółka z siedzibą w Londynie, notowana na Londyńskiej Giełdzie Papierów Wartościowych. Właściciel ponad 300 tytułów prasowych oraz 200 serwisów internetowych w Holandii, Danii, Norwegii i Polsce (http://www.mecom.com/Businessoverview.aspx - dostęp z 10 stycznia 2012 r.). 
mutacji są przygotowywane jednak w ten sposób, aby zachować markę funkcjonującą przed fuzją, również w artykułach stosowane jest powszechnie sformułowanie „Głos Szczeciński”.

Ogółem zbadano 298 pierwszych stron „Głosu Dziennika Pomorza - Szczecin”13, czyli wszystkie numery, które ukazały się w 2010 r. Analizie poddano tytuły i tematykę materiałów czołówkowych. Sygnały technik tabloidyzacyjnych stwierdzono w 169 pierwszostronicowych artykułach czołówkowych, co oznacza 56,71 proc. badanego materiału.

Ustalając strukturę technik świadczących o czerpaniu z palety zabiegów stosowanych przez redakcje tabloidów wykorzystano prace Walerego Pisarka. Prasoznawca, omawiając typologię gazet, wymienia cechy tzw. „stylu tabloidowego": rzucającą się w oczy szatę graficzną (w tym przewagę ilustracji nad tekstem); zainteresowanie zwykłymi sprawami zwykłych ludzi, plotkami z życia osób wybitnych, wydarzeniami niezwykłymi, często z kręgu erotyki i zbrodni; posługiwanie się potocznymi, łatwo rozumianymi formami językowymi i stylistycznymi, prostymi zdaniami, językiem nasyconym emocjami, zaimkami „my”, „nam”, neologizmami, mieszaniem faktów i opinii w jednej wypowiedzi; stosowaniem strategii udramatyzowanego opowiadania, upraszczającego i personalizującego stan rzeczy; skupianie uwagi raczej na osobach niż na ich działaniu; stosowanie w selekcji wydarzeń raczej kryterium sensacyjności i zdolności do wywoływania wrażenia niż ich społecznej ważności ${ }^{14}$.

Jako sygnały stosowania technik tabloidyzacyjnych wyselekcjonowano następujące decyzje redakcyjne, w zakresie tematyki: sensacyjna tematyka treści artykułu; historia pojedynczej osoby, rodziny lub niewielkiej grupy osób; w zakresie konstrukcji tytułu: identyfikacja z odbiorcą osiagana przez stosowanie zaimków, a także czasowników w pierwszej osobie liczby mnogiej; użycie języka uznawanego za potoczny; hiperbolizacja, przesada skutkująca nieadekwatnością treści artykułu do jego tytułu; bezpośrednie eksponowanie emocji w tytułach; nawiązania do sfery intymnej życia człowieka; opisy drastycznych, szokujących szczegółów w tytułach; bezpośrednie apelowanie do czytelnika; jednoznaczna, krytyczna ocena bohaterów tekstu.

13 W dalszej części pracy użyto skrótu „GDP Sz”.

14 W. Pisarek, Wstęp do nauki o komunikowaniu, Warszawa 2008, s. 134. 


\section{Wyniki badań}

Wykres 1. Obecność sygnałów tabloidyzacyjnych w tytulach artykułów czołówkowych opublikowanych na 298 pierwszych stronach „Glosu Dziennika Pomorza - Szczecin” w 2010 r.

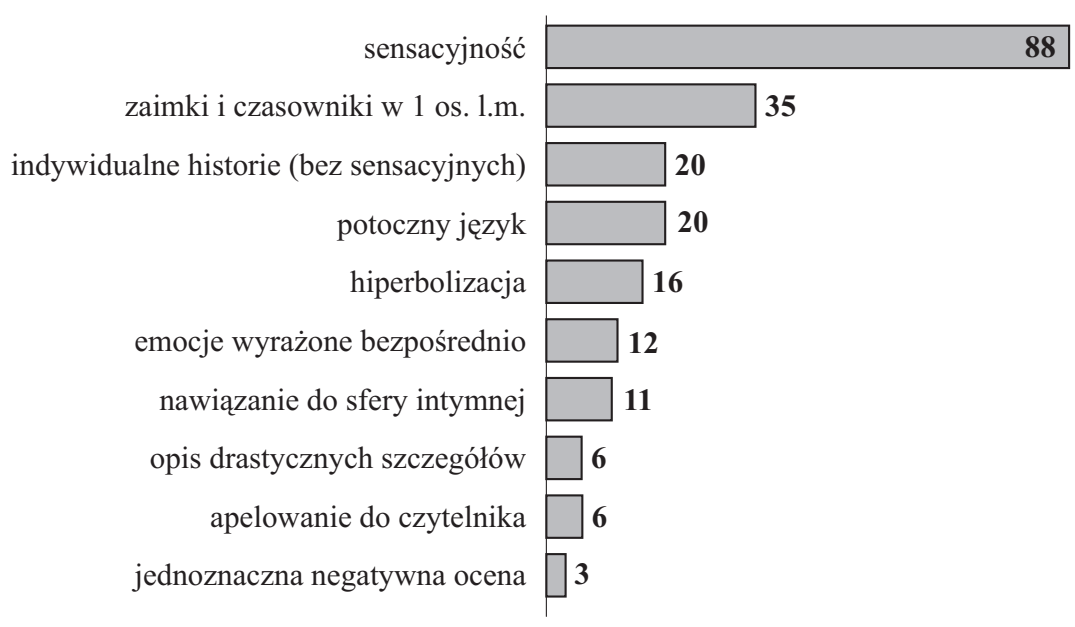

Źródło: Opracowanie własne.

Podczas analizy materiału stwierdzono obecność 88 artykułów noszących znamiona sensacyjności, co stanowi 29,53 proc. wszystkich tekstów czołówkowych. Dotyczyły one wydarzeń aktualnych: wypadków, np. Śmierć $w$ elektrowni ${ }^{15}$, Wybuch $w$ wieżowcu ${ }^{16}$, Wybuch butli $z$ gazem zabit pracownika ${ }^{17}$, Mur runat na robotników ${ }^{18}$ oraz bieżących wydarzeń kryminalnych, np. Napadt na bank i uciekt - wystraszyly go kasjerki $^{19}$, Zginat, bo stanat $w$ obronie dziewczyny ${ }^{20}$, Zabit matke za Smoleńsk ${ }^{21}$, Pijana babcia $z$ wnukiem ${ }^{22}$, Podpalali co 100 metrów $^{23}$.

„GDP Sz” 1.02.2010.

17 „GDP Sz” 5.02.2010.

18 „GDP Sz" 29.04.2010.

19 „GDP Sz” 12.02.2010.

20 "GDP Sz" 5-6.06.2010

21 „GDP Sz” 22.04.2010.

22 „GDP Sz” 10.05.2010.

23 „GDP Sz” 27.05.2010.
} 
W drugiej grupie w większości są to: artykuły oparte na informacjach dotyczących śledztw prowadzonych przez prokuratorów (z treści tekstów można wnioskować, że są to głównie teksty oparte na aktach oskarżenia przesłanych przez prokuratury do sądów), np. Kolejni podejrzani $w$ ZUS $^{24}$, Policjant z zarzutem - gwalt $i$ stręczycielstwo ${ }^{25}$, Zarobiła na ofiarach $^{26}$, Śmierć pod dyskotekq ${ }^{27}$, Starosta u prokuratora ${ }^{28}$, Szukaja ofiar. Dziecięca pornografia w komórce ${ }^{29}$, Milion za zły poród ${ }^{30}$, Wyczyścili taśme prawdy ${ }^{31}, 17$ lekarzy oskarżonych o branie tapówek ${ }^{32}$; relacje z procesów sądowych, np. Artur B. miat rozmawiać, Grzegorz M. wiózt tapówkę ${ }^{33}$, Trzy rzędy psychiatrów ${ }^{34}$, Trener przed sqdem ${ }^{35}$ oraz materiały, które powstały po ogłoszeniu wyroku, np. Za oszusta ma przeprosić, za głupka już nie ${ }^{36}$, Kupiła głosy, straci fotel ${ }^{37}$, Ksiadz posiedzi krócej $^{38}$, Dr Barbie do więzienia ${ }^{39}$, Ukarali handlarza ludźmi ${ }^{40}$, Wyrok za listy śmierci ${ }^{41}$, Winny śmierci od extasy ${ }^{42}$, Piłkarze skazani ${ }^{43}$.

Jako osobną kategorię wyróżniono artykuły, w których redakcja zajmuje się problemami dotyczącymi pojedynczej osoby. W analizowanym materiale stwierdzono 20 materiałów czołówkowych $(6,71$ proc.) spełniających ten warunek, np. teksty dotyczące jednej osoby (Ptatny dojazd do garażu ${ }^{44}$, Zamurowali mu drzwi ${ }^{45}$, Wiktor czeka na

„GDP Sz” 16-17.01.2010.

„GDP Sz” 27-28.02.2010.

„GDP Sz” 8.04.2010.

„GDP Sz” 4.05.2010.

„GDP Sz” 23.06.2010.

„GDP Sz” 25.08.2010.

„GDP Sz” 2.09.2010.

„GDP Sz” 10.09.2010.

„GDP Sz” 13.09.2010.

„GDP Sz” 28.01.2010.

„GDP Sz” 1.04.2010.

„GDP Sz” 10-11.04.2010.

„GDP Sz” 13-14.03.2010.

„GDP Sz” 18.03.2010.

„GDP Sz” 20-21.03.2010.

„GDP Sz” 26.02.2010.

„GDP Sz” 2.07.2010.

„GDP Sz” 15.12.2010.

„GDP Sz” 14.05.2010.

„GDP Sz” 16.06.2010.

„GDP Sz” 12.08.2010.

„GDP Sz” 5.10.2010. 
watrobe $e^{46}$ ), poruszający problemy trzech osób (Stracity prace przez $G G^{47}$ ) oraz na temat historii dwunastu rodzin (Jak żyć bez pradu $i w_{o d y}{ }^{48}$ ). Należy podkreślić, że do tej grupy zakwalifikowano jedynie artykuły niesensacyjne. Są to, tzw. historie zwykłych ludzi, z których czytelnik może przeczytać o problemach mężczyzny któremu zamurowano wejście do mieszkania i który musi wychodzić z domu przez okno, poruszającej historii młodego mężczyzny który zatruł się grzybami i czeka na przeszczep wątroby lub o sprawie zwolnienia trzech kobiet, które w czasie pracy plotkowały na temat koleżanek za pośrednictwem komunikatora internetowego.

Typowe dla budowania tekstów w prasie brukowej jest dążenie do identyfikacji czytelnika z tytułem prasowym. Najprostszym sposobem na osiagnnięcie tego celu jest użycie w tytule konstrukcji składniowej wskazującej na to, że redakcja stawia się w sytuacjach konfliktowych po stronie „Zwykłych ludzi”. Zabiegiem stosowanym najczęściej było używanie w tytule zaimków, np. Nasza przedsiębiorcza Elżbieta Teresińska $^{49}$, Nasi najlepsi piłkarze ${ }^{50}$, Nasze atomowe nadzieje $e^{51}$, Ile zarabia nasza władza ${ }^{52}$, Dziś ma nas bronić piasek ${ }^{53}$, Na taka straż nas nie stac $^{54}$, To u nas ruszyta kampania ${ }^{55}$, Powódź zabrała nam turystów $z$ poludnia ${ }^{56}$, Zostawili nam pociagi Intercity bez ochrony ${ }^{57}$, Awans przystuży się nam wszystkim ${ }^{58}$, Grozi nam powódź zima ${ }^{59}$, Śnieg nas przydusit $^{60}$, Sprzedali nas jak bydło ${ }^{61}$, Zima nam nie odpuściła ${ }^{62}$, Nasze

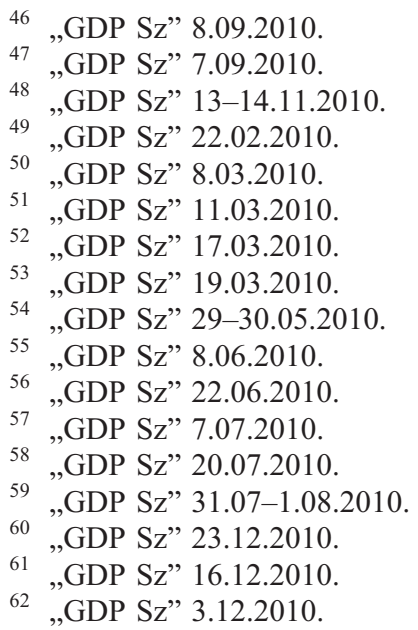


tańcza najlepiej $^{63}$, Wybraliśmy nasze wladze ${ }^{64}$, PiS ma dla nas receptę ${ }^{65}$, Nie kompromitujcie nas! $!^{66}$, To auto nas podglada ${ }^{67}$. Drugą techniką jest używanie czasowników w pierwszej osobie liczby mnogiej, np. Pójdziemy Festiwalowa Aleja ${ }^{68}$, Teraz dostaniemy duże pieniadze na Stru$\mathrm{ga}^{69}$, Pożegnamy ich w sobotę ${ }^{70}$, Będziemy mieli kolej ${ }^{71}$, Bawiliśmy się na Wałach! $!^{72}$, Wkrótce będziemy mieć Europę $w$ autobusach ${ }^{73}$, Mamy 55 kilometrów $^{74}$, Boże! Pozabijamy się $t u^{75}$. Zastosowanie takiego zabiegu stwierdzono w 35 tytułach (11,75 proc. badanych tekstów).

Język uznawany za potoczny zastosowano przy konstrukcji tytułów 20 artykułów pierwszostronicowych (6,71 proc. wszystkich artykułów). Jako przykłady można wymienić: To kreatura nie czlowiek $^{76}$, Na lodzie $z$ kredytami $^{77}$, Śnieg daje nam $w$ kośc $^{78}$, Zabić mógt klient burdelu ${ }^{79}$, Tani odlot bez recepty ${ }^{80}$, Na to choruja czyścioszki ${ }^{81}$, Znów nam ściemniaja $^{82}$, Gryfice sq $w$ szoku ${ }^{83}$, Mtyn $w$ aptekach $i$ taxi ${ }^{84}, C B A$ węszy w szkołach ${ }^{85}$, Gwiazdy się rozkręcaja ${ }^{86}$.

Hiperbolizacja, przesada, stosowanie nieadekwatnych do sytuacji określeń służy udramatyzowaniu przekazu. Może to prowadzić do niezgodności

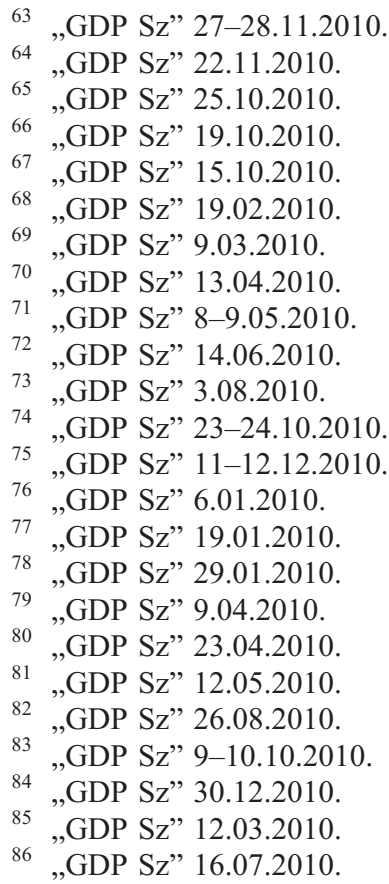


tytułu z treścią artykułu. Do tej kategorii zakwalifikowano 16 tytułów (5,37 proc. całości materiału), m.in. Bałtyk zamarza powoli ${ }^{87}$ (temat: morze nie zamarzło, więc lodołamacze czekają na sygnał do wypłynięcia), Koszmar kierowcó $w^{88}$ (problemy z parkowaniem spowodowane śniegiem zalegającym na chodnikach), Zabili symbole pokoju ${ }^{89}$ (śmierć kilkudziesięciu gołębi spowodowana zamknięciem okien na strychu kamienicy), Wielkie wyrzucanie z kolejek do lekarza ${ }^{90}$ (sprawdzanie list pacjentów pod kątem kilkakrotnej rejestracji na ten sam zabieg w różnych placówkach), Straciliśmy trzy życia ${ }^{91}$ (opis wypadku drogowego), Odra zatarła granice ${ }^{92}$ (opis efektów powodzi, podczas której woda zalała niezamieszkane tereny położone zarówno po polskiej, jak niemieckiej stronie granicy), Nocna bitwa o waty ${ }^{93}$ (relacja $\mathrm{z}$ działań prowadzonych w czasie powodzi), Telefoniczny terrorysta uderzyt $w$ magistrat $^{94}$ (dwa fałszywe alarmy na temat bomby podłożonej w urzędzie miejskim), Deszcz pomógł ukryć łzy ${ }^{95}$ (relacja z obchodów 30. rocznicy podpisania Porozumień Sierpniowych), Chemiczna psychoza ${ }^{96}$ (możliwe zwolnienia w Zakładach Chemicznych Police), Kuba terroryzuje szkołę (5-letni uczeń źle zachowuje się w szkole), $W$ grobie obok psa ${ }^{98}$ (opis serwisu internetowego oferującego możliwość wpisywania kondolencji nie tylko z powodu zmarłych osób, ale również zwierząt).

Wyrażenie emocji wprost stwierdzono w 12 nagłówkach (4,03 proc.), np. Kuria wściekta na radnych ${ }^{99}$, Jesteśmy bezradni wobec cmentarnych hien ${ }^{100}$, Ludzie boja się grypy ${ }^{101}$, Plany wielkie. Strach też ${ }^{102}$, Polska kocha swoje szybkie dziewczyny ${ }^{103}$.

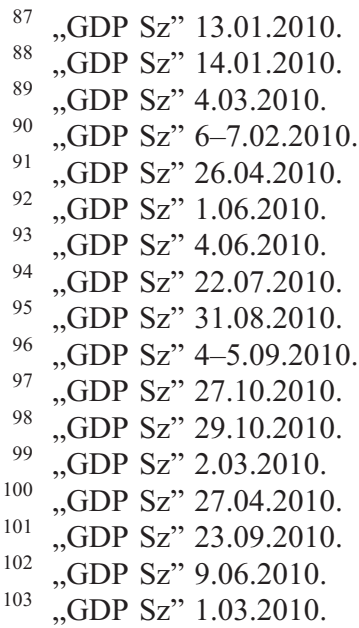


Nawiązanie do sfery intymnej życia człowieka w tytułach artykułów stwierdzono w 11 przypadkach (3,69 proc.). Stosowano tę technikę w nagłówkach tekstów o przestępstwach seksualnych (Seryjny leśny gwałciciel $^{104}$ ) lub przestępstw, w których pewną role odgrywała erotyka (Grozit mu pornozdjęciami ${ }^{105}$, Listonosz chciat seksu ${ }^{106}$, Gimnazjalistka $i$ ich pięciu $^{107}$ ), materiałach interwencyjnych (Erotoman zajmuje linię ${ }^{108}$ ), a nawet w tekstach o osobach zajmujących się propagowaniem wiedzy ekonomicznej (Oszczędzaniem ze świnka i seksem ${ }^{109}$ ).

Apelowanie jest zabiegiem pokrewnym do identyfikacji z czytelnikiem. Redakcja dąży do nawiązania dialogu z odbiorcą, stosując tytuły, w których zwraca się do niego bezpośrednio. Tę technikę redakcja zastosowała w sześciu przypadkach (2,01 proc.): Oddaj głos na Marysię! $!^{110}$, Masz dtug? Bój się e-sqdu! ${ }^{111}$, Latem nie stój w korkach ${ }^{112}$, Strzė̇ się tych ludzi ${ }^{113}$, Tu ukradna twoje auto ${ }^{114}$, Możesz zostać żakiem ${ }^{115}$.

Jako sygnał tabloidyzacyjny wyróżniono eksponowanie w tytułach artykułów czołówkowych drastycznych, szokujących szczegółów. Redakcja zdecydowała się na ten krok w sześciu przypadkach (2,01 proc.): Chca, żeby syn pracowat z dziura $w$ glowie ${ }^{116}$, Chciat mnie zgwatcić, potem zabic ${ }^{117}$, Wbit żonie nóż $w$ szyje i zabit się $w$ aucie ${ }^{118}$, Ludzkie kości walaja się pod nogami dzieci ${ }^{119}$, Podpalit żonę $i$ dziecko ${ }^{120}$, Czaszki leża wśród śmieci ${ }^{121}$.

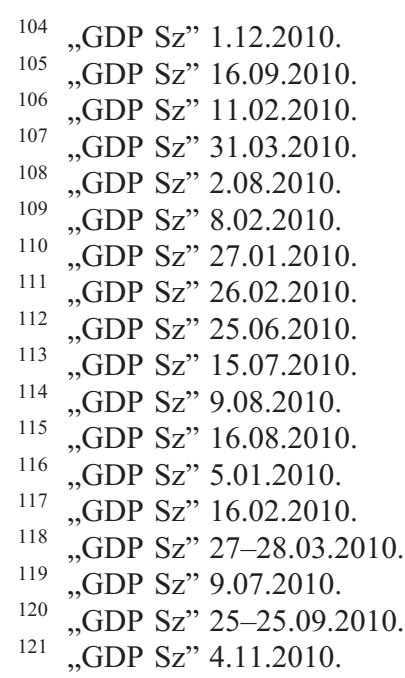


Jednoznaczną, ostrą i negatywną ocenę bohaterów tekstu stwierdzono w trzech przypadkach (1,01 proc.). Wszystkie artykuły dotyczyły wyroków i postanowień wydawanych przez sąd: To kreatura, nie człowiek $^{122}$, Sad nie miat litości dla wyrodnych rodziców ${ }^{123}$, Bestia wrócita za kraty $^{124}$.

\section{Wnioski}

W zakresie doboru tematyki, najpopularniejszą techniką okazała się decyzja o publikacji artykułu sensacyjnego. Skandal nie jest, co prawda, wynalazkiem tabloidów: John B. Thompson przypomina przykłady na jego obecność w mediach pochodzące już z końca XVII wieku ${ }^{125}$, jednak przewaga sensacji i skandalu nad „tematami poważnymi” jest dzisiaj obecna $\mathrm{w}$ tabloidach niejako $\mathrm{z}$ definicji. W analizowanym dzienniku stwierdzono charakterystyczny sposób doboru tematów. Większość z tekstów oparta była na wiarygodnych źródłach: wypowiedziach przedstawicieli policji lub prokuratury, aktach oskarżenia skierowanych do sądów, zeznaniach świadków oraz opiniach biegłych prezentowanych podczas procesów lub wreszcie na informacjach pochodzących z posiedzeń sądów, na których odczytywane były wyroki. Przygotowywanie tekstów na podstawie wiarygodnych relacji pozwala przypuszczać, że redakcja stara się przy pomocy tabloidowych technik dostarczyć czytelnikowi treści, które mogą znaleźć się w każdej gazecie ogólnoinformacyjnej głównego nurtu. Łamana jest więc tutaj jedna z podstawowych cech prasy tabloidowej, brak paktu faktograficznego. Jest to istotne ze względu na podstawowe zasady polityki redakcyjnej, gdyż jak pisze Małgorzata Lisowska-Magdziarz, w przypadku tabloidów ,nie tylko nie zakłada się podawania wyłącznie informacji sprawdzonych, lecz buduje się informacje z domysłów, spekulacji, sprowokowanych zachowań i wypowiedzi"126. Można więc przyjąć, że publikowane w „GDP Sz” wiadomości, mimo iż sensacyjne, są prawdziwe. W przypadku prasy

\footnotetext{
122 „GDP Sz” 6.01.2010.

123 „GDP Sz” 20.01.2010.

124 "GDP Sz" 12.10.2010.

125 J. B. Thompson, Skandal polityczny. Władza i jawność w epoce medialnej, Warszawa 2010, s. 61-80.

126 M. Lisowska-Magdziarz, Media powszechne..., op. cit., s. 196.
} 
brukowej nie jest to oczywiste. Fakt ten zauważają czytelnicy tabloidów, część odbiorców traktuje nawet publikowane tam informacje jako nie tyle źródło wiedzy o otaczającym ich świeci, ile źródło rozrywki ${ }^{127}$.

Drugim polem tematycznym eksploatowanym przez redakcję „GDP Sz" są problemy pojedynczych osób lub niewielkich grup. Tego tematu dotyczyło 20 artykułów czołówkowych. Denis McQuail przywołuje opinię dotyczącą amerykańskich wiadomości telewizyjnych, wedle której „pojawiła się tendencja do personalizacji i dramatyzacji, która ułatwia wielu osobom dostęp do wiadomości, prowadzi jednak do trywializacji tego, czego się ludzie z wiadomości dowiadują"128. Według Elizabeth Bird, ,cechą stylu tabloidowego jest kładzenie silnego akcentu na przeżycia jednostki, poważne wydarzenia ekonomiczne lub polityczne przedstawiane są przez pryzmat osobistych historii pojedynczych osób lub rodzin" ${ }^{\prime 129}$. Teksty zaliczone do tej kategorii nie poruszają tematów ważnych dla ogółu, ani nie dotyczą większej zbiorowości, choćby mieszkańców jednego osiedla lub miejscowości. Ich głównym zadaniem jest oddziaływaniem na emocje odbiorcy, wzruszenie go, zszokowanie lub rozbawienie. Publikacja takiego artykułu w gazecie regionalnej, jaką jest „GDP Sz” jest ryzykowna, ponieważ zasięg mutacji obejmuje byłe województwo szczecińskie, czyli niespełna milion mieszkańców. $Z$ tego powodu historie muszą być dobrane tak, aby zainteresowały pozostałych czytelników. Tzw. „historie zwykłych ludzi” dotyczą problemów, z którymi stykaja, lub mogą się zetknąć, odbiorcy tekstu. Pracownicy redakcji tabloidów zakładają, że czytelnicy identyfikują się z osobami borykającymi się z niesprawiedliwością pracodawców, irracjonalnymi decyzjami aparatu urzędniczego, bezdusznością służby zdrowia, codziennymi problemami z administracją. Wszystkie te techniki można zaobserwować w „GDP Sz”. Zaobserwowano tu nie tylko materiały o wymowie negatywnej (12 artykułów), ale również teksty mające na celu pochwalenie działań bohaterów (osiem artykułów).

Wśród technik stosowanych $\mathrm{w}$ czasie redagowania tytułu $\mathrm{w}$ analizowanym materiale najczęściej stwierdzano zabiegi identyfikowania czytelnika z gazetą. Odpowiednią konstrukcję składniową zastosowano

127 S. Allan, Kultura newsów, Kraków 2006, s. 107-113.

128 D. McQuail, Teoria komunikowania masowego, Warszawa 2008, s. 139.

129 S. E. Bird, Tabloidization: What is it and Does it Really Matter, w: The Changing Faces of Journalism Tabloidization Technology and Truthiness, red. B. Zelizer, Nowy Jork 2009, s. 41. 
częściej niż w co dziesiątym tytule czołówkowym. Redakcja przy pomocy tego zabiegu dzieli z czytelnikami ich problemy (np. Śnieg daje nam $w$ kośc $c^{130}$ ), buduje w odbiorcach wysokie poczucie własnej wartości, docenienia (np. Będziemy mieli kolej ${ }^{131}$ ), stawia się w roli obrońcy interesów czytelników (np. Na takq straż nas nie stać ${ }^{132}$ ), a nawet podkreśla wspólne uczestnictwo $\mathrm{w}$ wydarzeniach (np. Bawiliśmy się na Wałach! ${ }^{133}$ ). Przy tak dużej frekwencji stosowania tego zabiegu łatwo o przesadę i wywołanie wrażenia wręcz sztucznego narzucania się czytelnikowi, wmuszania mu poglądów, z którymi się nie utożsamia.

Podobną pułapką jest hiperbolizacja w tytułach. Jest zrozumiałe, że redaktorzy chcą przyciagnąć uwagę odbiorcy i zachęcić go do kupienia gazety przez podkreślenie lub wyolbrzymienie tytułu. Może jednak dojść do sytuacji, że tytuł zamiast poruszać - śmieszy. Nie jest to zagrożenie dla wizerunku mediów tabloidowych, jednak w przypadku gazety informacyjnej może zaważyć na jej odbiorze, nie tylko przez kupujących pismo, ale również przez reklamodawców oraz środowiska opiniotwórcze.

Jedną z charakterystycznych cech stylu tabloidowego jest odwoływanie się do emocji odbiorcy. Uczucia wyrażone wprost stwierdzono w dwunastu nagłówkach, ale tytułów, w których położono większy nacisk na afekt, niż na treść informacyjną można wymienić więcej. Strach przed mniej lub bardziej realnym zagrożeniem, współczucie dla bohaterów tekstu, duma z miasta lub regionu, złość na ogólnie pojętą władzę, administrację, aparat urzędniczy - to uczucia, których wywołanie często usprawiedliwia zepchnięcie na dalszy plan wartości informacyjnej tytułu.

Największy wpływ na wizerunek gazety wydaje się mieć tendencja do używania w tytułach artykułów pierwszostronicowych języka potocznego, niekiedy - wulgarnego. Publikowanie sformułowań takich jak „burdel”, „kreatura”, „być w szoku” w najbardziej prestiżowym miejscu gazety może w świadomości odbiorcy wywołać wrażenie kontaktu $\mathrm{z}$ prasą należącą do segmentu tabloidów.

Nie zauważono natomiast innych ważnych cech prasy tabloidowej, m.in. krzykliwych kolorów, wyróżniającej się czcionki oraz dominacji grafiki nad tekstem. Redagowanie graficzne szczecińskiego wydania „Głosu Dziennika Pomorza” oparte jest na layoucie charakterystycznym

\footnotetext{
130 „GDP Sz” 29.01.2010.

„GDP Sz” 8-9.05.2010.

132 „GDP Sz” 29-30.05.2010.

133 „GDP Sz” 14.06.2010.
} 
dla wszystkich mutacji tego tytułu. Charakterystyczne jest umieszczanie jednego lub dwóch głównych tekstów. Artykuł czołówkowy zilustrowany jest jedną stosunkowo dużą fotografią (incydentalnie dwoma lub trzema). Jeśli materiał pozbawiony jest elementów graficznych, funkcję „drugiej czołówki” pełni krótki tekst ze zdjęciem.

Tabela 1

Sposób organizacji przestrzeni na 298 pierwszych stronach

„Głosu Dziennika Pomorza - Szczecin” w 2010 r.

\begin{tabular}{|c|c|c|c|}
\hline Sposób organizacji przestrzeni & \multicolumn{3}{|c|}{ Liczba } \\
\hline Jeden materiał główny ze zdjęciem & & & 154 \\
\hline \multirow[t]{4}{*}{ Dwa główne materiały } & \multicolumn{3}{|r|}{131} \\
\hline & \multirow[t]{3}{*}{ w tym: } & $\begin{array}{l}\text { materiał czołówkowy ilustrowany } \\
+ \text { drugi materiał }\end{array}$ & 24 \\
\hline & & $\begin{array}{l}\text { materiał czołówkowy }+ \text { drugi ma- } \\
\text { teriał ilustrowany }\end{array}$ & 105 \\
\hline & & oba główne materiały ilustrowane & 2 \\
\hline Niestandardowe rozwiazania graficzne & & & 13 \\
\hline
\end{tabular}

Źródło: Opracowanie własne.

Czcionka stosowana w tytułach jest jednolita dla wszystkich wydań, nie są używane jej inne rozmiary punktowe. Do wyjątków (niestandardowe rozwiązania graficzne) zaliczają się pierwsze strony poświęcone ważnym lub wyjątkowym wydarzeniom: katastrofie samolotu pod Smoleńskiem oraz związanych $\mathrm{z}$ nią ceremoniom pogrzebowym (3 wydania), wyborom prezydenckim (2 wydania), Igrzyskom Olimpijskim w Vancouver (2 wydania), ogłoszeniu Jana Pawła II błogosławionym, obchodom rocznicy podpisania Porozumień Sierpniowych, zarobkom władz województwa i gmin (po jednym wydaniu). Opublikowano również 3 pierwsze strony, na których zamiast standardowego artykułu czołówkowego znalazły się życzenia redakcji dla czytelników z okazji Wielkiej Nocy, Bożego Narodzenia oraz nadchodzącego nowego roku. Proporcje te nie odbiegają od praktyki redakcyjnej w innych dziennikach.

Nie zanotowano również typowej dla tabloidów tendencji skupiania się na życiu osób znanych, gwiazd, tzw. celebrytów. Powodem jest zapewne brak takich osób w regionie. Warto jednak dodać, że w dwóch przypadkach tematem materiału czołówkowego były wydarzenia dotyczące Festiwalu Gwiazd odbywającego się co roku w Międzyzdrojach 
(Gwiazdy się rozkręcaja ${ }^{134}$ oraz Gwiazdy świecq u nas ${ }^{135}$ ). Można przypuszczać, że to pole tematyczne byłoby chętniej eksploatowane przez redakcję, jeśli istniałaby w Szczecinie szeroka grupa powszechnie znanych osób związanych ze światem rozrywki.

Podsumowując należy zauważyć, że redakcja „GDP Sz” przejęła językowe techniki właściwe dla stylu tabloidowego i stosuje je przy konstruowaniu tytułów głównych tekstów w gazecie, czyli artykułów czołówkowych publikowanych na pierwszych stronach. Niektóre wskaźniki analizy ilościowej wydają się niskie. Obecność niektórych sygnałów tabloidyzacyjnych stwierdzono jedynie w kilku procentach publikacji poddanych analizie. Wrażenie to może być jednak mylne. Badano tylko artykuły czołówkowe z pierwszych stron gazety, co oznacza, że są one najbardziej wizerunkowe i reprezentatywne dla polityki redakcji. Skutki dla wizerunku tytułu mogą być widoczne, nawet jeśli ukaże się kilka materiałów opatrzonych tytułami jednoznacznie łamiącymi konwencję przyjętą w dziennikach głównego nurtu.

Odpowiedź na pytanie o przyczyny wprowadzania technik tabloidowych do praktyki redakcyjnej leży zapewne w chęci zdobycia nowych odbiorców, których upodobania czytelnicze ukształtował „Fakt”, „Super Express" oraz audycje telewizyjne przygotowywane zgodnie z zasadami infotainment. Jest również przejawem szerszej tendencji obejmującej nie tylko dzienniki regionalne. Małgorzata Lisowska-Magdziarz przyznaje, że „ogólny trend w semiotyce i estetyce mediów jest właśnie trendem w stronę semiotyki i estetyki tabloidu"136. Sukces prasy tabloidowej zachęca wydawców nie tylko do zmian w już istniejących tytułach, ale nawet do tworzenia nowych. Przykładem może być „Nowy Dzień”, dziennik który ukazywał się jedynie prze 102 dni na przełomie $2005 \mathrm{r}$. i 2006 r. $^{137}$

W przypadku szczecińskiej mutacji „Głosu Dziennika Pomorza” można mówić jeszcze o innej przyczynie stosowania w redagowaniu stylu tabloidowego. Gazeta do 1989 r. była organem Polskiej Zjednoczonej Partii Robotniczej i mimo że od tamtego okresu minęło kilkadziesiąt lat, znacząca grupa czytelników wciąż pamięta specyfikę dziennikarstwa,

\footnotetext{
134 „GDP Sz” 16.07.2010.

135 „GDP Sz” 17.07.2010.

136 M. Lisowska-Magdziarz, Media powszechne..., op. cit., s. 204.

137 I. Hofman, „Nowy Dzień” - nieudany eksperyment Agory, w: Współczesne media. Wolne media, t. 2, red. I. Hofman, D. Kępa-Figura, Lublin 2010, s. 87.
} 
z którym można było się spotkać wtedy na łamach tytułu. Jest to szczególnie ważne w kontekście rywalizacji z bezpośrednim konkurentem „Głosu” - „Kurierem Szczecińskim”, postrzeganym jako gazeta poruszająca „lżejszą tematykę”. Należy zaznaczyć, że w rzeczywistości te różnice między oboma tytułami dawno już zanikły, jednak jak się okazuje pozostały w świadomości odbiorców. Robert Cieślak, analizując przeobrażenia prasy szczecińskiej, podaje wyniki prowadzonych w $1999 \mathrm{r}$. wśród czytelników badań jakościowych, z których wynika, że „,choć deklarowano, że przeszłość nie ma znaczenia przy decyzji o zakupie, to wciąż pamiętano genezę gazety partyjnej, kojarzonej z hasłem »proletariusze wszystkich krajów łączcie się«"138. Można wnioskować, że konsekwentne stosowanie tabloidowych taktyk redakcyjnych leży także w chęci odcięcia się od wizerunku gazety „mentorskiej” i „nudnej”.

\section{Bibliografia}

Allan S., Kultura newsów, Kraków 2006.

Bajka Z., Rynek mediów w Polsce, w: Dziennikarstwo i świat mediów. Nowa edycja, red. Z. Bauer, E. Chudziński, Kraków 2008.

Bauer Z., ,, Twój głos w Twoim domu”: cztery typy tabloidyzacji, w: Oblicza komunikacji. Język i kultura tabloidów. Wroctaw 29-30 czerwca 2009. Materiaty konferencyjne, www.oblicza.konferencja.org/ufiles/File/ksiazka_przedkonferencyjna.pdf (dostęp z 10 stycznia 2012 r.).

Białek-Szwed O., ,, Super Express” - pierwszy polski tabloid (studium przypadku), „iNFOTEZY” 2012, nr 1.

Bird S. E., Tabloidization: What is it and Does it Really Matter, w: The Changing Faces of Journalism Tabloidization Technology and Truthiness, red. B. Zelizer, Nowy Jork 2009.

Ciborowska E., Transformacja prasy bytej PZPR, „Zeszyty Prasoznawcze” 1992, nr $1-2$.

Cieślak R., Przeobrażenia prasy regionalnej w Zachodniopomorskiem na przykładzie „,Glosu Szczecińskiego”, w: Środki masowego komunikowania a spoteczeństwo, red. M. Gierula, Katowice 2006.

Filas R., Rynek prasy codziennej w Polsce przed „Faktem” i z „Faktem”, „Zeszyty Prasoznawcze" 2005, nr 3-4.

138 R. Cieślak, Przeobrażenia prasy regionalnej..., op. cit., s. 140. 
Hofman I., ,, Nowy Dzień” - nieudany eksperyment Agory, w: Współczesne media. Wolne media, tom. 2, red. I. Hofman, D. Kępa-Figura, Lublin 2010.

Keen A., Kult amatora. Jak internet niszczy kulture, Warszawa 2007.

Klimkiewicz B., Krajobraz medialny w Polsce: struktura własności i pluralizm mediów, w: Własność medialna i jej wptyw na pluralizm oraz niezależność mediów, red. B. Klimkiewicz, Kraków 2005.

Kowalski T., Jung B., Media na rynku. Wprowadzenie do ekonomiki mediów, Warszawa 2006.

Lisowska-Magdziarz M., Media powszechne. Środki komunikowania masowego i szerokie paradygmaty medialne w życiu codziennym Polaków u progu XXI wieku, Kraków 2008.

McQuail D., Teoria komunikowania masowego, Warszawa 2008.

Pisarek W., Wstęp do nauki o komunikowaniu, Warszawa 2008.

Poulet B., Śmierć gazet i przyszłość informacji, Wołowiec 2011.

Przyszłość dziennikarstwa $w$ dojrzałych demokracjach, red. P. J. Anderson, G. Ward, Warszawa 2010.

Thompson J. B., Skandal polityczny. Władza i jawność w epoce medialnej, Warszawa 2010.

www.mecom.com/Businessoverview.aspx (dostęp z 10 stycznia 2012 r.).

\section{The application of tabloidization techniques as an element of editorial strategy in the regional press - the case of Szczecin}

\section{Summary}

The paper examines the local version of the Głos Dziennik Pomorza newspaper, on the assumption that in order to maintain levels of readership, viewership and listenership even the quality media are beginning to resort to what has so far been the source of the popularity of tabloids. A total of 298 front pages of the Glos Dziennik Pomorza - Szczecin were examined, accounting for every issue published in 2010. The analysis covered the headlines and content of leading articles. Symptoms of tabloidization techniques were found in 169 of front page leading articles, which accounted for 56.71 percent of the material investigated. Therefore, it can be concluded that the editorial board of the Głos Dziennik Pomorza - Szczecin has adopted linguistic techniques typical of a tabloid-like style, applying them to the headlines of the leading articles published on the front page of the newspaper. Some results of the quantitative analysis appear to be quite low. Only a small percentage of the articles analyzed show some symptoms of tabloidization. This impression can be misleading, though. The analysis covered only the leading articles from the front pages of the newspaper, which are most influential for its image and most representative of the policy of the editorial board. 
